Stawomir Steinborn

Uniwersytet Gdański

\title{
NOWY MODEL PRZEKAZYWANIA SKAZANYCH MIĘDZY PAŃSTWAMI UNII EUROPEJSKIEJ? UWAGI NA TLE ZAKRESU RATIONE PERSONAE INSTYTUCJ
}

\section{Uwagi wprowadzające}

Swoboda przemieszczania się, z jakiej korzystają obywatele Unii Europejskiej, będąca niewątpliwym czynnikiem integracyjnym, w sferze zwalczania przestępczości jest jednak źródłem dodatkowych trudności i komplikacji. Swobodnie podróżować między poszczególnymi państwami członkowskimi mogą bowiem nie tylko „praworządni” obywatele, ale również członkowie grup przestępczych, osoby, które na terytorium innego państwa członkowskiego upatrują lepszych warunków i sposobności do popełniania przestępstw, jak też osoby, które ukrywają się przed organami ścigania i wymiarem sprawiedliwości jednego z państw członkowskich. Przekroczenie granicy państwa, zwłaszcza w strefie Schengen, możliwe jest w bardzo krótkim czasie, podczas gdy przekazanie osoby ściganej lub skazanej z jednego państwa do drugiego wymaga wdrożenia skomplikowanych i czasochłonnych procedur. Nie może zatem być zaskoczeniem, że państwa członkowskie niemal od pierwszych chwil, kiedy powstała idea zniesienia kontroli granicznych w państwach strefy Schengen, podejmują - z różnym skutkiem - próby uproszczenia i usprawnienia współpracy w sprawach karnych między państwami członkowskimi ${ }^{1}$. Niewątpliwym sukcesem w tej sferze jest wprowadzona przed ponad dziesięciu laty instytucja europejskiego nakazu aresztowania, która na obszarze Unii Europejskiej zastąpiła ekstradycję ${ }^{2}$ Dzięki niej możliwe jest sprawne przekazywanie osób ściganych w celu przeprowadzenia w jednym państwie członkowskim postępowania karnego lub wykonania tam kary pozbawienia wolności, które to osoby znajdują się na tery-

1 W kwestii historii współpracy unijnej w sprawach karnych zob. szerzej A. Lach, (w:) A. Grzelak, M. Królikowski, A. Sakowicz (red.), Europejskie prawo karne, Warszawa 2012, s. 33 i n.

2 Decyzja ramowa z dnia 13 czerwca 2002 r. w sprawie europejskiego nakazu aresztowania i procedury wydawania osób między Państwami Członkowskimi (2002/584/WSiSW), Dz.U. WE L Nr 190 z dnia 18 maja 2002 r., s. 1 in. 
torium innego państwa członkowskiego. Nie ma potrzeby przypominania dyskusji, jakie towarzyszyły wprowadzaniu w państwach członkowskich europejskiego nakazu aresztowania i były żywe zwłaszcza w pierwszych latach jej funkcjonowania. Obecnie jesteśmy świadkami wprowadzania przez państwa członkowskie nowego, równie jak europejski nakaz aresztowania znaczącego instrumentu współpracy w sprawach karnych, a mianowicie instytucji przekazywania skazanych między państwami członkowskimi Unii Europejskiej. Przewidująca go decyzja ramowa Rady 2008/909/WSiSW o stosowaniu zasady wzajemnego uznawania do wyroków skazujących na karę pozbawienia wolności lub inny środek polegający na pozbawieniu wolności - w celu wykonania tych wyroków w Unii Europejskiej (nazywana dalej decyzją ramową) $)^{3}$ przyjęta została przez Radę w listopadzie 2008 r., zaś dnia 5 grudnia 2011 r. minął termin, w którym państwa członkowskie UE miały implementować w swoim prawie krajowym. Polska, obok 17 innych państw członkowskich ${ }^{4}$, wywiązała się już z tego obowiązku, czego wyrazem są przepisy zawarte w dodanych w k.p.k. rozdziałach 66f i 66g . Można sądzić, że w najbliższym czasie do grupy tej dołączą pozostałe państwa członkowskie UE. Skłania to do tego, aby zastanowić się, w jakim stopniu wprowadzenie jej w życie będzie oznaczało zmianę dotychczasowego modelu przekazywania skazanych, opartego na konwencji o przekazywaniu osób skazanych sporządzonej w Strasburgu dnia 21 marca 1983 r. (nazywanej dalej konwencją strasburską) ${ }^{6}$. Być może zmiany, jakie następują w tej sferze, są tak znaczące, że należałoby mówić o nowym modelu? Pewne analogie do europejskiego nakazu aresztowania nie są pozbawione podstaw. Również w przypadku przekazywania skazanych mamy bowiem do czynienia $\mathrm{z}$ instrumentem ściśle wiążącym się z pozbawieniem jednostki wolności. Zmierza się tu do uproszczenia, usprawnienia i przyspieszenia procedury przekazywania skazanych między państwami członkowskimi UE oraz usunięcia zbędnych biurokratycznych barier, m.in. poprzez eliminację kompetencji organu administracyjno-politycznego i ukształtowanie całej procedury uznania wyroku i przekazania skazanego jako postępowania toczącego się wyłącznie przed organem sądowym. Niewątpliwie przełoży się to - podobnie jak było to w przypadku ekstradycji i ENA - na zwiększenie, w porównaniu ze stanem dotychczasowym pod rządami konwencji strasburskiej, częstotliwości korzystania z tej instytucji. Liczba cudzoziemców - obywateli UE odbywających kary pozbawienia wolności w poszczególnych państwach członkowskich pozwala również sądzić, że instrument ten będzie miał istotne praktyczne znaczenie w sferze unijnej współpracy w sprawach karnych. Wprowadzenie tego nowego instrumentu będzie miało istotne konsekwencje dla polskiego wymiaru sprawiedliwości i systemu penitencjarnego.

Dz. Urz. UE L 328 z 5 grudnia 2008 r., s. 27 ze zm.

Stan na dzień 15 kwietnia $2014 \mathrm{r}$.

Zob. art. 1 pkt 3 ustawy z dnia 16 września 2011 r. o zmianie ustawy - Kodeks postępowania karnego, ustawy o prokuraturze oraz ustawy o Krajowym Rejestrze Karnym (Dz.U. z 2011 r. Nr 240, poz. 1430). 
Nowy model przekazywania skazanych między państwami Unii Europejskiej?...

Wystarczy wskazać, że w 2010 r. w krajach UE przebywało około 3.700 obywateli polskich skazanych na karę pozbawienia wolności, a jednocześnie należy liczyć się z tendencją wzrostową liczby obywateli polskich przebywających w zakładach karnych w innych państwach UE. W tym samym 2010 r. liczba tymczasowo aresztowanych obywateli polskich w innych państwach członkowskich wynosiła bowiem około 8.700 osób. Jednocześnie jednak w 2010 r. w polskich zakładach karnych karę pozbawienia wolności odbywało tylko 226 obywateli innych państw członkowskich $\mathrm{UE}^{7}$. Można zatem spodziewać się, że po wygaśnięciu w 2016 r. przewidzianej w decyzji ramowej klauzuli wyłączającej możliwość przekazania do Polski skazanych bez ich zgody, zostanie przekazana do Polski liczba kilku tysięcy skazanych. W sensie ilościowym spodziewać się zatem należy istotnej zmiany, skoro bowiem liczba skazanych przekazywanych do i z Polski w oparciu o konwencję strasburską jest zasadniczo mniejsza (należy przy tym pamiętać, że krąg państw-stron konwencji strasburskiej jest szerszy i istotnie wykracza poza państwa członkowskie UE). Przykładowo w 2007 r. do Polski zostało w tym trybie przekazanych 72 skazanych, zaś z Polski tylko $13^{8}$.

W dalszych rozważaniach podjęta zostanie porównawcza analiza unormowań dotyczących zakresu podmiotowego instytucji przekazywania skazanych oraz ściśle łączącej się z nim kwestii zgody skazanego przyjętych w konwencji strasburskiej z 1983 r. oraz w decyzji ramowej. Analiza ta niewątpliwie może ułatwić sformułowanie odpowiedzi na pytanie, czy obserwując wprowadzanie w Unii Europejskiej nowych zasad przekazywania skazanych między państwami członkowskimi jesteśmy jednocześnie świadkami tworzenia nowego systemu przekazywania skazanych, czy też mamy do czynienia wyłącznie ze skorygowaniem systemu dotychczasowego. Porównanie rozwiązań konwencyjnych i unijnych może jednocześnie ułatwić zidentyfikowanie problemów, z jakimi przyjdzie się wraz z wprowadzaniem nowych zasad zmierzyć.

\section{Zakres podmiotowy przekazania}

Instytucja przekazywania skazanych ma u swoich podstaw przede wszystkim uzasadnienie humanitarne, gdyż jej celem jest umożliwienie skazanemu powrotu do państwa, z którym łączą go rzeczywiste i ścisłe więzi, zwłaszcza rodzinne, społeczne i kulturowe, w celu odbycia tam kary pozbawienia wolności. Niewątpliwie bowiem większe są szanse powodzenia procesu resocjalizacji skazanego, jeżeli będzie się on znajdował będzie on w kraju, w którym możliwy jest stały kontakt z rodziną, brak jest barier językowych i kulturowych, a skazany nie doświadcza złego trakto-

\footnotetext{
7 Dane podaję za uzasadnieniem projektu ustawy o zmianie ustawy - Kodeks postępowania karnego, ustawy o prokuraturze oraz ustawy o Krajowym Rejestrze Karnym (druk sejmowy nr 4586/VI z 17 sierpnia 2011 r.). Podaję za R. Kierzynka, Przekazywanie skazanych na karę pozbawienia wolności w Europie, „Ius Novum” 2009, nr 2, s. 111.
} 
wania ze strony współwięźniów lub funkcjonariuszy więziennych, co nierzadko jest udziałem skazanych obcokrajowców. Przekazywanie skazanych, w odróżnieniu od ekstradycji i europejskiego nakazu aresztowania, nie jest więc instrumentem współpracy podejmowanej wyłącznie w interesie państw, zwłaszcza państwa skazania i państwa wykonania kary, lecz przede wszystkim w interesie samych skazanych ${ }^{9}$. Z pewnością dążenie niektórych przynajmniej państw członkowskich do stworzenia efektywnego mechanizmu przekazywania skazanych cudzoziemców, motywowane chęcią odciążenia własnego systemu penitencjarnego, nie powinno być traktowane jako główny cel nowych unormowań, jak również nieuzasadnione byłoby przyznanie mu istotnego waloru interpretacyjnego $\mathrm{w}$ analizie nowych rozwiązań. $Z$ tego też względu kluczowe znaczenie ma sprecyzowanie kryterium pozwalającego na ustalenie państwa, z którym skazanego łączą tak ścisłe więzi, iż uzasadnione jest jego przekazanie w celu wykonania tam kary pozbawienia wolności.

Zakres podmiotowy przekazania na podstawie konwencji strasburskiej oparty jest na kryterium obywatelstwa (art. 3 ust. 1 lit. a). Przekazaniu podlegać może zatem wyłącznie obywatel państwa, do którego ma nastąpić przekazanie skazanego w celu wykonania kary pozbawienia wolności. Podstawową zaletą tego kryterium jest jego prostota i jednoznaczność, bowiem w praktyce obywatelstwo skazanego można ustalić o wiele łatwiej niż inne okoliczności mające świadczyć o związkach z danym krajem. Z drugiej jednak strony, nie zawsze skazany musi mieć swoje centrum życiowe w kraju obywatelstwa, gdyż o wiele silniejsze więzi mogą łączyć go $\mathrm{z}$ innym krajem ${ }^{10}$. Rozwiązanie przyjęte w konwencji strasburskiej jest o tyle bezpieczne z punktu widzenia skazanego, że co do zasady nie ma możliwości przymusowego przekazania skazanego do państwa, którego jest obywatelem, lecz nie ma w nim miejsca zamieszkania, gdyż generalnie konwencja uzależnia przekazanie od zgody skazanego. Kryterium obywatelstwa nie stwarza zatem w tym aspekcie zagrożeń dla interesów skazanego, gdyż nie ma możliwości przekazania go bez jego zgody do państwa, którego jest obywatelem. Trudno zaś zakładać, że skazany mając luźne związki z państwem, którego jest obywatelem, wyrazi zgodę na przekazanie do niego w celu wykonania tam kary. Jednocześnie jednak nie jest dopuszczalne w oparciu o tę konwencję przekazanie skazanego do innego państwa niż kraj jego obywatelstwa, nawet jeżeli w tym państwie skazany ma miejsce zamieszkania i swoje centrum życiowe, a zatem należałoby zakładać, że lepiej będzie przebiegać proces resocjalizacji skazanego. Przekazanie w tym przypadku nie jest dopuszczalne również wówczas, gdyby skazany tego przekazania chciał. Kryterium obywatelstwa jest zatem mało elastyczne w wyznaczaniu zakresu podmiotowego przekazania. Pewne złagodzenie konsekwencji tak sztywno określonego kryterium podmiotowego stanowi przepis art. 3 ust. 4 konwencji strasburskiej, który umożliwia określe- 
Nowy model przekazywania skazanych między państwami Unii Europejskiej?...

nie w drodze oświadczenia złożonego wobec Sekretarza Generalnego Rady Europy, definicji pojęcia „obywatel” w rozumieniu tej konwencji. Na tej podstawie niektóre państwa-strony konwencji rozciągnęły jej zastosowanie na cudzoziemców mających w nich miejsce zamieszkania (Szwecja, Dania, Finlandia, Holandia).

W sposób zdecydowanie bardziej złożony unormowany został zakres podmiotowy przekazania skazanych między państwami członkowskimi UE w oparciu o decyzję ramową 2008/909/WSiSW. W celu uzyskania całościowego obrazu tego, kto, na jakich warunkach i do jakiego państwa może zostać przekazany, należy wziąć pod uwagę również kwestię zgody skazanego oraz zgody państwa wykonania kary. Każde z określonych w art. 4 ust. 1 decyzji ramowej kryteriów wyznaczających potencjalne państwo wykonania orzeczenia i w ten sposób określających zakres podmiotowy przekazania z uwagi na więź łączącą to państwo ze skazanym, wymaga odrębnej analizy.

Głównym kryterium zastosowanym przez ustawodawcę europejskiego jest kryterium obywatelstwa połączonego z zamieszkaniem (art. 4 ust. 1 lit. a) decyzji ramowej). W teorii prawa międzynarodowej współpracy w sprawach karnych taką konfigurację nazywa się kryterium ograniczonego obywatelstwa. Polega ono na tym, że samo obywatelstwo nie uznaje się za wystarczające dla oznaczenia zakresu osób podlegających przekazaniu, lecz łączy się je z innym, dodatkowym kryterium. Najczęściej jest nim kryterium domicylu lub miejsca zamieszkania. Kryterium to opiera się na założeniu, że sam fakt, iż skazany jest obywatelem określonego państwa nie musi jeszcze sam w sobie uzasadniać odbycia w nim kary, jeżeli życie i działalność zawodowa skazanego koncentrują się w innym państwie ${ }^{11}$. Niewątpliwą zaletą takiego rozwiązania jest to, że do przekazania nie jest wystarczające istnienie węzła prawnego w postaci obywatelstwa między określonym państwem a skazanym, lecz konieczne jest również istnienie powiązania faktycznego z tym państwem przejawiającego się w posiadaniu w nim swojego centrum życiowego. Z założenia zatem skazany nie powinien być przekazany do przypadkowego państwa. W ten sposób większe są szanse realizacji podstawowego celu przekazania, jakim jest lepsza resocjalizacja skazanego. Konsekwencją przyjęcia tego kryterium jest zawężenie zakresu podmiotowego przekazania, gdyż konieczne jest kumulatywne spełnienie dwóch przesłanek - obywatelstwa i zamieszkania. Wadą tego kryterium jest natomiast to, że z zakresu podmiotowego przekazania wyłączone są osoby, które skupiły swoją aktywność życiową i zawodową na terytorium państwa, którego nie są obywatelami. W przypadku tego kryterium pewna dodatkowa praktyczna trudność może brać się jedynie z tego, że określenie kryterium miejsca zamieszkania nie jest tak proste, jak kryterium obywatelstwa, gdyż odwołuje się ono do okoliczności o charakterze faktycznym, które muszą zostać w toku postępowania ustalone. 
Błędem byłoby jednak sądzić, że skoro w powyższej sytuacji przyjęto kryterium ograniczonego obywatelstwa, to zakres podmiotowy przekazania skazanych między państwami członkowskimi UE jest węższy niż w przypadku konwencji strasburskiej, która opiera się na kryterium obywatelstwa. Trzeba bowiem pamiętać o dwóch kolejnych sytuacjach określających zakres podmiotowy przekazania między państwami UE. Zgodnie z art. 4 ust. 1 lit. b) decyzji ramowej, przekazany może zostać również skazany będący obywatelem państwa wykonania, nawet jeśli nie mieszka w tym państwie, jeżeli na mocy odpowiedniej decyzji ma zostać po zwolnieniu z wykonania kary wydalony lub deportowany z państwa skazania do państwa, którego jest obywatelem. Kryterium przekazania jest w tym przypadku obywatelstwo połączone $\mathrm{z}$ istnieniem decyzji o wydaleniu skazanego. Istotny jest tu fakt, iż w tym przypadku nie jest wymagana zgoda skazanego na przekazanie. Mamy tu zatem do czynienia z powieleniem rozwiązania przewidzianego $\mathrm{w}$ art. 3 Protokołu dodatkowego do konwencji strasburskiej, który w takie sytuacji wyjątkowo zezwala na przekazanie skazanego bez jego zgody do państwa, którego jest obywatelem.

Na marginesie pierwszej i drugiej sytuacji warto zauważyć, iż decyzja ramowa nie wyklucza przekazania osób posiadających podwójne obywatelstwo. Podobnie, jak w przypadku konwencji strasburskiej, istotny jest jedynie fakt posiadania obywatelstwa państwa wykonania, a zatem w razie braku przeszkód wewnętrznych, dopuszczalne jest przekazanie osoby, która obok obywatelstwa państwa wykonania ma również obywatelstwo państwa skazania. $Z$ drugiej jednak strony, państwo skazania może potraktować fakt posiadania przez skazanego jego obywatelstwa za podstawę rezygnacji z przekazania skazanego.

Trzecie kryterium wyznaczające zakres podmiotowy przekazania określone zostało w art. 4 ust. 1 lit. c) decyzji ramowej i ma niezmiernie szeroki charakter. Zgodnie bowiem z tym przepisem przekazanie może nastąpić także do innego państwa członkowskiego niż państwo, którego obywatelem jest skazany i jednocześnie ma w nim miejsce zamieszkania oraz państwo, którego jest obywatelem i do którego ma zostać wydalony, jeżeli tylko właściwy organ tego innego państwa wyrazi zgodę na przekazanie skazanego i wykonanie w nim kary pozbawienia wolności. Drugim warunkiem przekazania jest zgoda skazanego (art. 6 ust. 1 decyzji ramowej). W ten sposób zakres podmiotowy przekazania na podstawie decyzji ramowej uzyskał niemal nieograniczony charakter. Przekazany nie musi bowiem być ani obywatelem państwa wykonania, ani nawet obywatelem Unii Europejskiej, jak również nie musi też w tym państwie mieć miejsca zamieszkania. Takie rozwiązanie stanowi niewątpliwe novum w porównaniu $\mathrm{z}$ tradycyjnym modelem przekazywania skazanych, a zbliżone jest nieco do rozwiązania funkcjonującego w odniesieniu do przekazywania skazanych między państwami skandynawskimi ${ }^{12}$. Ustawodawca europejski wyszedł tu z założenia, że nie ma powodów, aby uniemożliwiać przekazanie kary 
pozbawienia wolności do wykonania w innym państwie członkowskim niż państwo, którego obywatelem jest skazany i w którym jednocześnie ma on miejsce zamieszkania, skoro zgadzają się na to zarówno państwo skazania (występując o jej wykonanie w innym państwie członkowskim), państwo wykonania i w końcu sam skazany. Elastyczność omawianego rozwiązania przejawia się przede wszystkim w tym, że ocenie współpracujących państw, przede wszystkim państwa wykonania oraz ocenie skazanego pozostawione zostało, czy więzy (o jakimkolwiek charakterze prawnym lub faktycznym) istniejące między skazanym a państwem, do którego miałby on potencjalnie zostać przekazany, są na tyle silne, że uzasadniają przekazanie. $\mathrm{W}$ omawianej sytuacji decyzja ramowa w art. 4 ust. 3 przewiduje jedynie obowiązek przeprowadzenia konsultacji między państwem skazania a państwem wykonania. Ich celem jest ustalenie, że wykonanie kary przez państwo wykonania będzie sprzyjało i ułatwi resocjalizację skazanego. Powyższe rozwiązanie niewątpliwie największą użyteczność wykazywało będzie w odniesieniu do skazanych, którzy mają miejsce zamieszkania w innym państwie członkowskim niż państwo, którego są obywatelami. Umożliwia ono bowiem przekazanie takiej osoby nie do państwa, którego jest obywatelem, lecz do państwa, w którym mieszka i z którym stworzył silne i stałe więzy. Dzięki temu możliwe jest odbycie kary pozbawienia wolności w pobliżu rodziny i przyjaciół i utrzymywanie z nimi bliskich i regularnych kontaktów, co niewątpliwie sprzyja efektywniejszej resocjalizacji.

Reasumując tę część rozważań, należy stwierdzić, że zakres ratione personae w unijnym systemie przekazywania skazanych w porównaniu z konwencją strasburską cechuje się większą elastycznością i umożliwia przekazanie każdego skazanego, o ile taka będzie wola obu państw i samego skazanego.

\section{Problem zgody skazanego na przekazanie}

Analizując unormowania dotyczące zakresu podmiotowego przekazania można zadać sobie pytanie, dlaczego przyjmując tak szerokie i elastyczne rozwiązanie, jak zawarte w art. 4 ust. 1 lit. c) decyzji ramowej, ustawodawca europejski przewidział jeszcze w art. 4 ust. 1 lit. a) kryterium ograniczonego obywatelstwa? Uzyskanie pełni obrazu regulacji zawartej w decyzji ramowej i odniesienia jej do dotychczasowego systemu funkcjonującego na podstawie konwencji strasburskiej wymaga uwzględnienia dwóch dodatkowych czynników, a mianowicie kwestii wymogu zgody skazanego na przekazanie ${ }^{13}$ oraz zgody państwa wykonania. W dwóch pierwszych omówionych wyżej przypadkach, a więc w razie przekazania skazanego

13 Art. 6 ust. 2 decyzji ramowej regulujący sytuacje, kiedy zgoda skazanego nie jest wymagana, został implementowany w art. $611 \mathrm{t} \S 5$ k.p.k. oraz art. $611 \mathrm{tk} \S 1$ pkt 3 k.p.k. Trudno podzielić zastrzeżenia A. Górskiego dotyczące prawidłowości implementacji rozwiązań decyzji ramowej wyrażone na tle przepisów art. 611t § 1, 3 i 5 k.p.k. - zob. K.T. Boratyńska, A. Górski, A. Sakowicz, A. Ważny, Kodeks postępowania karnego. Komentarz, Warszawa 2013, s. 1200-1201. 
do państwa, którego jest obywatelem i jednocześnie ma w nim miejsce zamieszkania (art. 4 ust. 1 lit. a) decyzji ramowej) oraz w razie przekazania do państwa, którego skazany jest obywatelem i do którego ma zostać wydalony, nie jest wymagana ani zgoda skazanego (art. 6 ust. 2 lit. a) i b) decyzji ramowej), ani zgoda państwa wykonania (art. 4 ust. 3 a contrario decyzji ramowej). Mamy tu zatem do czynienia z istotnym odejściem od reguł przyjętych w konwencji strasburskiej, gdyż ta w pierwszej sytuacji wprawdzie przyjmuje szersze kryterium obywatelstwa, jednak co do zasady wymaga zgody skazanego na przekazanie (art. 3 ust. 1 lit. d) konwencji strasburskiej) oraz w każdym przypadku zgody państwa wykonania (art. 3 ust. 1 lit. f) konwencji strasburskiej) ${ }^{14}$, zaś $\mathrm{w}$ drugim przypadku wprawdzie również nie wymaga zgody skazanego na przekazanie, lecz nie wprowadza tu wyjątku od wymogu uzyskania zgody państwa wykonania (art. 3 ust. 2 Protokołu dodatkowego do konwencji strasburskiej). Zgoda skazanego nie jest również wymagana w sytuacji, gdy zbiegł on z państwa skazania w celu uniknięcia toczącego się tam postępowania karnego lub odbycia prawomocnie orzeczonej kary pozbawienia wolności (art. 6 ust. 2 lit. c) decyzji ramowej). W zbliżonej sytuacji przekazanie może nastąpić również bez zgody skazanego w systemie przekazywania skazanych opartym na konwencji strasburskiej (zob. art. 2 ust. 3 Protokołu dodatkowego), z tym że nadal wymagana jest zgoda państwa wykonania.

Można zatem stwierdzić, że w systemie przekazywania skazanych opartym na konwencji strasburskiej skazany ma w postępowaniu zmierzającym do przekazania go z jednego państwa do drugiego co do zasady status podmiotu, a nie przedmiotu arbitralnych działań organów władzy, co wyraża się w wiążącym dla właściwych organów państwa skazania charakterze jego oświadczenia o zgodzie na przekazanie lub jej odmowie ${ }^{15}$. Nie bez racji twierdzi się natomiast, że w unijnym systemie przekazywania skazanych wymaganie zgody skazanego będzie miało marginalne znaczenie ${ }^{16}$. Wprawdzie decyzja ramowa - jakby rekompensując brak wymogu zgody skazanego - nakłada obowiązek umożliwienia skazanemu wyrażenia stanowiska w przedmiocie przekazania oraz jego uwzględnienia przy podejmowaniu decyzji w przedmiocie przekazania (zob. art. 6 ust. 3 decyzji ramowej), jednak z drugiej strony nie przewiduje obowiązku zapewnienia skazanemu informacji o obowiązujących w państwie wykonania unormowaniach dotyczących adaptacji orzeczenia oraz zasad wykonania kary, w tym możliwości jej zmiany w toku wykonywania kary oraz zasad uzyskiwania przedterminowego zwolnienia i innych podobnych instytu-

\footnotetext{
14 Na kwestię tę zwracał uwagę Sąd Najwyższy w uzasadnieniu uchwały z dnia 3 marca 2009 r., I KZP 30/08, OSNKW 2009, nr 4, poz. 26, wskazując różnicę między przekazaniem skazanego w trybie konwencji strasburskiej a tzw. przekazaniem powrotnym skazanego przekazanego wcześniej w trybie europejskiego nakazu aresztowania.

Płachta, Przekazywanie skazanych w Unii Europejskiej: model sui generis czy twórcze rozwinięcie tradycyjnego systemu?, „Studia Europejskie” 2007, nr 4, s. 75; tenże, Przekazywanie skazanych między państwami: za ich zgodą czy bez zgody, „Rzeczpospolita” z 27.12.2006 r., nr 300. Zob. H. Kuczyńska, (w:) Europejskie prawo..., op. cit., s. 518.
} 
Nowy model przekazywania skazanych między państwami Unii Europejskiej?...

cji. W połączeniu z dyskrecjonalnymi w dużej mierze uprawnieniami państwa wykonania, powoduje to, że stanowisko skazanego ma w systemie unijnym raczej małe znaczenie $^{17}$. Tymczasem różnice w ustawodawstwie karnym poszczególnych państw członkowskich UE powodują, że może zaistnieć sytuacja, gdy wskutek przekazania skazany będzie dłużej odbywał karę ${ }^{18}$. Możliwe jest to chociażby w związku z różnymi unormowaniami dotyczącymi warunkowego przedterminowego zwolnienia w państwie skazania i państwie wykonania.

$\mathrm{Na}$ gruncie decyzji ramowej najwięcej wątpliwości wiąże się z pierwszą sytuacją, a więc przymusowym przekazaniem skazanego do państwa, którego jest obywatelem i w którym mieszka. W tym przypadku można uznać, że dopuszczalność przekazania opiera się na przyjętym przez ustawodawcę europejskiego domniemaniu istnienia silnej więzi między skazanym a państwem wykonania. Domniemanie to może zostać obalone w efekcie przeprowadzenia między państwem skazania a państwem wykonania konsultacji, o których mowa w art. 4 ust. 3 i 4 decyzji ramowej. W toku tych konsultacji państwo wykonania może przedstawić państwu skazania opinię i argumenty uzasadniające przekonanie, że wykonanie kary w tym pierwszym państwie nie ułatwiłoby ani resocjalizacji skazanego, ani jego pełnej reintegracji społecznej. Nie sposób nie widzieć w tym ostatnim rozwiązaniu próby ratowania humanitarnego oblicza instytucji przekazywania skazanych w wydaniu unijnym. Pytanie jednak brzmi, czy próba ta ma w ogóle szanse, aby uznać ją za udaną? Podstawowa wątpliwość, jaka się tu pojawia, zawiera się w pytaniu, czy możliwe jest osiągnięcie celu w postaci przyczynienia się do resocjalizacji skazanego, jeżeli przekazanie następuje wbrew jego woli? Trudno przecież zakładać, że skazany, który został zmuszony do odbycia kary w określonym państwie, będzie współdziałał z administracją więzienną tego państwa w dążeniu do jak najszybszej jego resocjalizacji. Po drugie zasady przekazywania skazanych między państwami UE obowiązujące w analizowanej sytuacji zakładają, że państwo skazania może przekazać skazanego, a państwo wykonania nie może odmówić przejęcia. Nawet zatem, jeśli państwo wykonania w toku procedury konsultacji przedstawi istotne argumenty przeciwko przekazaniu skazanego, to jednak nie ma ono możliwości zablokowania przekazania skazanego, gdyż w art. 9 decyzji ramowej nie przewidziano stosownej podstawy odmowy wykonania orzeczenia o karze pozbawienia wolności, na którą mógłby powołać się sąd państwa wykonania ${ }^{19}$. Państwo skazania nie musi zatem w ogóle brać pod uwagę stanowiska państwa wykonania i wbrew jego woli przekazać skazanego. Nie sposób zatem nie zgodzić się z oceną, że wraz z przyjęciem i wprowadzeniem w życie decyzji ramowej dokonuje się w odniesieniu do

17 Zob. G. Vermuelen, A. van Kalmthout, N. Paterson, M. Knapen, P. Verbeke, W. de Bondt, Cross-border execution of judgements involving deprivation of liberty in the EU. Overcoming legal and practical problems through flanking measures, Antwerpen 2011, s. 81.

18 Por. M. Płachta, Przekazywanie skazanych w Unii Europejskiej..., op. cit., s. 72-73.

19 Ibidem, s. 77-78. 
instytucji przekazywania skazanych w Unii Europejskiej przeniesienie punktu ciężkości z humanitarnego uzasadnienia tej instytucji powiązanego przede wszystkim z realizacją celów resocjalizacyjnych na zasadę wzajemnego uznawania ${ }^{20}$. Okazuje się bowiem, że w przypadku przekazania do państwa, którego obywatelem jest skazany i w którym ma on miejsce zamieszkania, państwo skazania może de facto jednostronnie zdecydować o przekazaniu skazanego i przekazanie to będzie skuteczne (zakładając brak podstaw odmowy wykonania orzeczenia określonych w art. 9 decyzji ramowej), nawet wbrew woli państwa wykonania i samego skazanego. Mamy więc tutaj do czynienia $\mathrm{z}$ mechanizmem niemal automatycznego przekazania. Trudno zatem oprzeć się wrażeniu, że największym beneficjentem nowego systemu przekazywania skazanych w UE będą nie sami skazani cudzoziemcy, lecz państwa członkowskie, które mają ,nadwyżkę” skazanych obywateli innych państw członkowskich w swoich więzieniach w stosunku do własnych obywateli odbywających karę pozbawienia wolności w innych państwach członkowskich i dzięki temu nie będą musiały ponosić kosztów wykonania kary pozbawienia wolności wobec obywateli innych państw członkowskich ${ }^{21}$. Okazuje się zatem, że instytucja przekazywania skazanych w wydaniu unijnym ma funkcjonować nie tylko w interesie skazanych, lecz również, a być może i przede wszystkim w interesie (przede wszystkim ekonomicznym) państw członkowskich ${ }^{22}$. W tym aspekcie uzyskuje ona charakter środka zapewniającego prawidłowe funkcjonowanie systemów wymiaru sprawiedliwości i systemów penitencjarnych w poszczególnych państwach członkowskich.

Przedstawione powyżej zastrzeżenia uzasadniają daleko idącą ostrożność w interpretacji unormowania zawartego w art. 4 ust. 1 lit. a) decyzji ramowej oraz implementujących go przepisach prawa krajowego. Tymczasem zasadnicze wątpliwości budzi sposób, w jaki wprowadzone zostało to unormowanie w prawie polskim. Zgodnie bowiem z art. 611t $\S 3$ pkt 1 k.p.k., sąd występuje o wykonanie kary pozbawienia wolności do państwa wykonania orzeczenia, którego skazany jest obywatelem i w którym skazany posiada stałe lub czasowe miejsce pobytu. Również $\mathrm{w}$ innych przepisach dotyczących wykonania z kolei orzeczeń wydanych $\mathrm{w}$ innych państwach członkowskich, również mowa jest o ,stałym lub czasowym miejscu pobytu na terytorium RP” (zob. art. 611 tk $\S 1$ pkt 3 lit. a) oraz $\S 4$ k.p.k.) lub na terytorium państwa wykonania orzeczenia (zob. art. 611t $\S 3$ pkt 3 k.p.k.). Należy tymczasem zwrócić uwagę, iż w decyzji ramowej (zob. np. art. 4 ust. 1 lit. a) konsekwentnie posłużono się terminem „mieszka” (ang. lives, niem. lebt), a dodatkowo w pkt 17 motywów znalazło się wyjaśnienie, iż ,ilekroć (...) mowa jest o państwie,

Ibidem, s. 75-76.

Por. R. Kierzynka, Przekazywanie..., op. cit., s. 105-106; M. Płachta, Przymusowe przekazywanie skazanych między państwami budzi wątpliwości, „Rzeczpospolita” z 23.02.2007 r., nr 46, który podaje przykład Wielkiej Brytanii, której rząd silnie popierał projekt decyzji ramowej - na koniec czerwca 2006 r. w tamtejszych więzieniach przebywało 2348 skazanych cudzoziemców, podczas gdy jedynie 801 Brytyjczyków odbywało takie kary za granicą.

Por. R. Kierzynka, Przekazywanie..., op. cit., s. 111. 
Nowy model przekazywania skazanych między państwami Unii Europejskiej?...

w którym osoba skazana «mieszka», oznacza to miejsce, z którym osoba ta jest związana poprzez zwykłe miejsce pobytu i poprzez takie elementy, jak rodzina oraz więzi społeczne i zawodowe". Wynika z tego w sposób jasny, iż ustawodawcy europejskiemu nie chodziło tu jedynie o miejsce jakiegokolwiek pobytu osoby skazanej, lecz o miejsce, w którym ona mieszka i z którym łączą go silne więzy uzasadniające wykonywanie tam kary pozbawienia wolności. Podkreślić należy, iż wskazane w tej definicji elementy, tzn. miejsce pobytu oraz istnienie więzi z państwem, powinny być spełnione kumulatywnie. Termin ,stałe miejsce pobytu” należy zatem rozumieć jako synonim pojęcia ,miejsce zamieszkania”, przy czym chodzi tu o zamieszkiwanie w określonej miejscowości na terytorium jednego z państw członkowskich UE z zamiarem stałego tam przebywania. Zasadnicze wątpliwości budzi natomiast posłużenie się terminem ,czasowe miejsce pobytu”. Oznacza on bowiem przebywanie w określonej miejscowości na terytorium jednego z państw członkowskich UE, które nie ma jednak charakteru pobytu stałego, a zatem jest to pobyt okresowy (np. w związku z wykonywaniem pracy w tym państwie), przemijający lub nawet okazjonalny (np. pobyt związany z wypoczynkiem, leczeniem itp.). Istotne jest również to, że skoro skazany ma mieć czasowe miejsce pobytu w innym państwie członkowskim, to jednocześnie implikuje to fakt, że oprócz tego posiada on miejsce stałego pobytu w Polsce, innym państwie członkowskim niż państwo czasowego pobytu lub nawet w państwie trzecim i właśnie w jednym $\mathrm{z}$ tych państw znajduje się jego centrum życiowe. Wątpliwe wydaje się, aby tak rozumiany wskazany termin odpowiadał wskazanym wyżej wnioskom, jakie wynikają z decyzji ramowej. Trudno bowiem uznać, aby względy humanitarne, czy też wzgląd na wychowawcze i zapobiegawcze cele kary, uzasadniały wykonanie kary pozbawienia wolności w państwie członkowskim UE, którego obywatelem skazany wprawdzie jest, ale nie ma tam stałego miejsca pobytu i jedynie okresowo w nim przebywa (np. z uwagi na pracę tam lub inną działalność zawodową), jednak nie łączą go z tym państwem bliższe więzi rodzinne lub społeczne. Jeżeli bowiem skazany swoje centrum życiowe ma w Polsce, nie ma powodu, aby należało przekazywać wykonanie orzeczonej wobec niego kary do państwa, którego jest obywatelem, nawet jeżeli ma tam miejsce czasowego pobytu. Powyższe wnioski doznają wsparcia w treści art. 4 ust. 7 decyzji ramowej, który daje podstawę do złożenia przez państwa członkowskie oświadczenia, iż nie jest wymagana ich zgoda na przekazanie w sytuacji, o której mowa w art. 4 ust. 1 lit. c) decyzji ramowej, jeżeli ,skazany mieszka i legalnie przebywa w sposób ciągły od co najmniej pięciu lat w państwie wykonania”. Nie można wprawdzie tego przepisu rozumieć jako definicji pojęcia ,zamieszkanie”, jednak wskazuje, że ustawodawcy europejskiemu chodzi o dłuższy i stały pobyt na terytorium określonego państwa członkowskiego. Reasumując, uznać należy, iż przepis art. 611t $\S 3$ pkt 1 k.p.k. w części mówiącej o czasowym miejscu pobytu jest wynikiem błędnej implementacji art. 4 ust. 1 lit. a) decyzji ramowej, gdyż nie mieści się w zakresie znaczeniowym pojęcia „mieszka”. Wydaje się zatem, że art. 611t $§ 3$ pkt 1 k.p.k. powinien 
być interpretowany z uwzględnieniem tego faktu i należy dążyć do nadania mu znaczenia zgodnego $\mathrm{z}$ treścią decyzji ramowej ${ }^{23}$.

Pomimo negatywnych niekiedy dla skazanego konsekwencji przekazania bez jego zgody do innego państwa członkowskiego, przekazanie to nie prowadzi do otwarcia możliwości jego ścigania lub wykonania kary pozbawienia wolności orzeczonej za inne czyny. Przepis art. 18 decyzji ramowej wyraźnie bowiem przewiduje, że w razie przekazania skazanego bez jego zgody, rozciąga się na niego ochrona wynikająca z zasady specjalności. Ustawodawca europejski utrzymał zatem zasadę leżącą u podstaw rozwiązania przyjętego $\mathrm{w}$ art. 3 protokołu dodatkowego, iż możliwości przekazania skazanego bez jego zgody musi towarzyszyć wprowadzenie w tym zakresie zasady specjalności ${ }^{24}$.

Warto również zwrócić uwagę, że widoczny w unormowaniach decyzji ramowej automatyzm w przekazywaniu skazanych nie ma symetrycznego charakteru. Wprawdzie w sytuacji wskazanej w art. 4 ust. 1 lit. a) decyzji ramowej państwo skazania może przekazać skazanego wbrew stanowisku państwa wykonania i samego skazanego, jednak w tej sytuacji nie powstaje po stronie skazanego lub zwłaszcza państwa wykonania żadne roszczenie o przekazanie skazanego. Zgodnie z art. 4 ust. 5 decyzji ramowej zarówno państwo wykonania, jak i sam skazany mogą wprawdzie zwrócić się do państwa skazania o przekazanie wyroku skazującego na karę pozbawienia wolności, jednak przepis ten jednoznacznie zastrzega, że wnioski te nie skutkują obowiązkiem przekazania wyroku przez państwo skazania. Zarówno skazany będący obywatelem innego państwa członkowskiego i mający tam miejsce zamieszkania, jak i samo to państwo członkowskie nie dysponują zatem żadnym odpowiednim instrumentem, który mógłby im umożliwić skłonienie państwa skazania do przekazania wyroku do wykonania w tym państwie członkowskim. Wydaje się natomiast na gruncie decyzji ramowej dopuszczalne, aby prawo krajowe przewidziało dla skazanego uprawnienie do żądania od państwa skazania przekazania go w celu wykonania kary pozbawienia wolności do państwa, którego jest obywatelem i w którym ma miejsce zamieszkania.

\section{Podsumowanie}

Rozstrzygnięcie pytania, czy mamy do czynienia z nowym modelem przekazywania skazanych w Europie, czy też jedynie z modyfikacją dotychczasowego wymaga oczywiście analizy nie tylko kwestii zakresu ratione personae, ale również pozostałych elementów konstrukcyjnych instytucji przekazywania skazanych.

23 Zob. również P. Hofmański, E. Sadzik, K. Zgryzek, Kodeks postępowania karnego. Komentarz, t. 3, P. Hofmański (red.), Warszawa 2012, s. 982-983; S. Steinborn, (w:) J. Grajewski, L.K. Paprzycki, S. Steinborn, Kodeks postępowania karnego. Komentarz, t. 2, L.K. Paprzycki (red.), Warszawa 2013, s. 1242-1243.

24 Zob. szerzej S. Steinborn, (w:) Europejskie prawo..., op. cit., s. 86-87; S. Steinborn, (w:) J. Grajewski, L.K. Paprzycki, S. Steinborn, Kodeks..., t. 2, op. cit., s. 1334-1335. 
Analiza regulacji dotyczących zakresu ratione personae przekazywania skazanych między państwami członkowskimi UE wskazuje jasno, że silne piętno odcisnęła na niej zasada wzajemnego uznawania. Szeroki, niemal nieograniczony jest bowiem zakres osób, które mogą być przekazywane, a wymóg zgody skazanego - w tradycyjnym systemie jeden z fundamentów tej instytucji - zszedł na plan dalszy, gdyż ma zastosowanie tylko w przypadku braku łącznika obywatelstwa między skazanym a ewentualnym państwem wykonania. Formułując oceny nowej regulacji przekazywania skazanych między państwami członkowskimi UE wskazuje się, że przekazywanie skazanych do państwa obywatelstwa traci charakter procedury wyjątkowej, a staje się „standardową regułą postępowania karnego", co w konsekwencji będzie powodować, że sprawca popełniający przestępstwo na terytorium innego państwa członkowskiego będzie musiał się liczyć z koniecznością odbycia kary we własnym $\mathrm{kraju}^{25}$. Sprzyjać temu z pewnością będzie rezygnacja z wymagania zgody państwa wykonania na przejęcie skazanych - własnych obywateli, co wprowadza daleko idący automatyzm przekazywania skazanych, podobnie jak ma to miejsce w przypadku przekazywania osób ściganych w trybie europejskiego nakazu aresztowania ${ }^{26}$. Ten krok należy akurat ocenić pozytywnie, gdyż samo w sobie nie skutkuje to uprzedmiotowieniem osoby skazanego, a sprzyja pełniejszej realizacji zasady wzajemnego uznawania.

25 R. Kierzynka, Przekazywanie..., op. cit., s. 111.

26 Na fakt, iż unijny system przekazywania skazanych odchodzi od woluntarystycznych zasad systemu opartego na konwencji strasburskiej i nabiera cech systemu przymusowego przekazywania zwracają uwagę również G. Vermuelen, A. van Kalmthout, N. Paterson, M. Knapen, P. Verbeke, W. de Bondt, Cross-border execution..., op. cit., s. 79. 


\section{NEW MODEL OF TRANSFER OF PRISONERS BETWEEN MEMBER STATES OF THE EUROPEAN UNION? SOME REMARKS TO THE SCOPE OF RATIONE PERSONAE}

Framework decision 2008/909/JHA of 27 November 2008, on the application of the principle of mutual recognition to judgments in criminal matters imposing custodial sentences, or measures involving deprivation of liberty for the purpose of their enforcement in the European Union, made significant changes in the European system for the transfer of prisoners. The main aim of this article is to compare the scope of the system of transfer of prisoners under the Strasbourg convention of 1983 with that of the new framework decision. This new instrument broadens the possibility of transfer of prisoners without their consent. What gives rise to serious concerns, is whether the humanitarian background of this institution is still adequate.

Keywords: transfer of prisoners, principle of mutual recognition, consent of prisoner 